\title{
Stability of a Ni-rich Ni-Ti-Zr high temperature shape memory alloy upon low temperature aging and thermal cycling
}

\author{
A.M. Pérez-Sierra ${ }^{1}$, J. Pons ${ }^{1 *}$, R. Santamarta ${ }^{1}$, I. Karaman ${ }^{2}$ and R.D. Noebe ${ }^{3}$ \\ 1. Departament de Física, Universitat de les Illes Balears, Ctra. de Valldemossa, km 7.5, \\ E07122 Palma de Mallorca, Spain. \\ 2. Department of Materials Science and Engineering, Texas A\&M University, College \\ Station, TX 77843, USA \\ 3. Structures and Materials Division, NASA Glenn Research Center, Cleveland, $\mathrm{OH}$ \\ 44135, USA
}

\begin{abstract}
The thermal stability of $\mathrm{Ni}_{50.3} \mathrm{Ti}_{29.7} \mathrm{Zr}_{20}$ with aging in austenite at $250{ }^{\circ} \mathrm{C}$ has been studied for three distinctive microstructures obtained after selected thermal treatments: precipitate free and containing two different sizes and densities of H-phase nanoprecipitates. The martensitic transformation is suppressed after 1-3 weeks aging, depending on the initial microstructure, due to a B2 phase instability in the form of short range atomic reordering within the $\mathrm{Ti}+\mathrm{Zr}$ sublattice, considered to be precursor to the H-phase precipitation. Thermal cycling leads to notable changes in the transformation temperatures, which strongly depends on the starting microstructure.
\end{abstract}

Keywords: Martensitic phase transformations, Shape memory alloys, Precipitation, Aging, Phase instability.

*Corresponding author. Email: jaume.pons@uib.es 
Ni-Ti shape memory alloys are used in a large number of applications owing to their good functional properties related to the thermoelastic martensitic transformation (MT). However, these properties are restricted to relatively low temperatures, as binary $\mathrm{Ni}-\mathrm{Ti}$ alloys do not have a MT above $100^{\circ} \mathrm{C}$ [1]. Many efforts have been focused on macroalloying additions to increase the transformation temperatures (TTs) while retaining, as much as possible, the beneficial properties of the binary alloy. As a result, Ni-Ti-X alloys with $\mathrm{X}=\mathrm{Pd}$, Pt or Au have been developed as high temperature shape memory alloys (HTSMAs) [2]. More recently, the attention has moved to Ni-rich Ni-Ti-Hf and $\mathrm{Ni}-\mathrm{Ti}-\mathrm{Zr}$ as economical alternatives to the alloys containing precious metals. The functional properties of Ni-rich $\mathrm{Ni}-\mathrm{Ti}-\mathrm{Hf} / \mathrm{Zr}$ can be modified by selected thermal treatments, particularly those inducing the precipitation of a new Ni-rich phase [3-15]. This precipitate phase, denoted as "H-phase" [16], is a superstructure of the B2 phase obtained from a recombination of the $\mathrm{Hf} / \mathrm{Zr}$ and $\mathrm{Ti}$ atoms in their sublattice followed by a shuffling of all the atoms $[16,17]$.

The Ni-Ti-Hf system so far has received the most attention, showing good thermal stability and excellent shape memory behavior under high loads, enabled by H-phase nanoprecipitation $[3,6-15]$. To the best of the authors' knowledge, only a few works dealing with Ni-rich $\mathrm{Ni}-\mathrm{Ti}-\mathrm{Zr}$ can be found in the literature. Sandu et al. studied the effects of aging on superelasticity tested under compression in alloys containing 6 at $\% \mathrm{Zr}$ and reported the precipitation of a new phase which was not fully identified at the time $[4,5]$. Santamarta et al. characterized the precipitated phase in several Ni-rich Ni-Ti$\mathrm{Zr} / \mathrm{Hf}$ alloys, identifying the same H-phase in both alloy families [17]. Finally, Evirgen et al. obtained good shape memory and superelasticity in tension in $\mathrm{Ni}_{50.3} \mathrm{Ti}_{34.7} \mathrm{Zr}_{15}$ and $\mathrm{Ni}_{50.3} \mathrm{Ti}_{29.7} \mathrm{Zr}_{20}$ alloys as a result of nanoscale $\mathrm{H}$-phase precipitation $[13,18,19]$. However, the optimal microstructures and functionalities of a potential HTSMA device, especially a HTSMA actuator, could be modified by long exposure of the material around the working temperatures, due to diffusive effects. Therefore, the aim of this paper is to study the stability of the MT under prolonged aging in austenite, close to the TTs, in the $\mathrm{Ni}_{50.3} \mathrm{Ti}_{29.7} \mathrm{Zr}_{20}$ alloy with different initial distributions of $\mathrm{H}$-phase precipitates. Furthermore, the stability of the transformation under thermal cycling is also investigated. 
High-purity elemental Ni (99.98\%), Ti (99.95\%) and Zr (99.9\%) constituents were vacuum induction melted under a protective partial pressure of argon in a graphite crucible and cast into a copper mold. The ingot of nominal composition $\mathrm{Ni}_{50.3} \mathrm{Ti}_{29.7} \mathrm{Zr}_{20}$ was subsequently homogenized at $1050^{\circ} \mathrm{C}$ for $72 \mathrm{~h}$, sealed in a mild steel can and hot extruded at $900{ }^{\circ} \mathrm{C}$ with an area reduction of 7:1. Samples were spark-cut from the extruded rod, encapsulated in quartz ampoules under argon and solution heat treated (SHT) at $900{ }^{\circ} \mathrm{C}$ for 1 hour followed by water quenching (WQ) by breaking the ampoule. Some specimens were subjected to additional thermal treatments to generate two characteristic distributions of $\mathrm{H}$-phase precipitates [13,17,18]: i) $3 \mathrm{~h}$ aging at $550^{\circ} \mathrm{C}$ followed by WQ (denoted as 550C) and ii) a 5 min hold at $700{ }^{\circ} \mathrm{C}$ followed by controlled furnace cooling to $100^{\circ} \mathrm{C}$ in $48 \mathrm{~h}$ and finally WQ (denoted as FC). The 550C treatment produces a high density of homogeneous spindle like nanometric precipitates providing the best alloy functionality, whereas the FC treatment results in elongated particles of hundreds of nanometers in length $[13,17,18]$. Finally, samples with both distributions of H-phase precipitates, together with precipitate-free SHT specimens for reference, were aged for extended times in the austenite state at $250{ }^{\circ} \mathrm{C}$ in air to investigate their thermal stability. DSC measurements were performed in TA Instruments DSC 2920 and METTLER TOLEDO DSC823e units at $10 \mathrm{~K} / \mathrm{min}$ cooling/heating rate. Conventional TEM (HITACHI H600 at 100kV) was used for microstructural characterization. The TEM samples were double jet electropolished in a solution of $30 \% \mathrm{HNO}_{3}$ in methanol at $-20{ }^{\circ} \mathrm{C}$.

Figure 1 shows the DSC thermograms of the different samples after aging at $250{ }^{\circ} \mathrm{C}$ compared with the initial state. Long term aging causes a complete suppression of the transformation peaks in the range of temperatures available by DSC (down to $-150{ }^{\circ} \mathrm{C}$ ), irrespective of the initial microstructure. After 1 week of aging, the transformation is already suppressed for SHT and 550C samples, whereas the FC alloy is more resistant to aging and still shows the MT peaks, but with a significant decrease in the transformation temperatures and transformation enthalpy change. The transformation is completely suppressed in the FC material after 3 weeks at $250{ }^{\circ} \mathrm{C}$. Moreover, the behavior of the SHT material was found to be strongly dependent on the effective quenching rate, as different samples treated separately showed different transformation behavior (not shown here), depending on the rapidity of the ampoule breaking process. In some cases, like that shown in Fig. 1, the initial thermogram after SHT indicates 
some inhomogeneity in the material, evidenced by a double transformation peak. Also, delays in breaking the ampoules and slow quenching rates were observed to lead to a complete suppression of the MT even without any additional low temperature aging treatment.

TEM observations performed after prolonged aging at $250^{\circ} \mathrm{C}$ ( 7 weeks) only revealed subtle microstructural changes. The aged SHT material showed a very fine mottled contrast in the bright field images accompanied by diffuse streaks in the diffraction patterns, as seen in Figs. 2(a) to 2(c). The fundamental spots in these patterns agree with the B2 phase, while the diffuse streaks have a linear shape connecting the fundamental spots in the $\langle 110\rangle$ directions and a more rounded shape along the $\langle 100\rangle$ directions. For the 550C and FC samples, aging at $250{ }^{\circ} \mathrm{C}$ did not cause significant changes in the preexisting H-phase particles. The main effects are diffuse streaks in the diffraction patterns similar to the SHT material, as shown in Figs. $2 \mathrm{~d}$ to $2 \mathrm{f}$. In this case, the B2 spots are accompanied by $1 / 2<111\rangle, n / 3<110\rangle$ and $n / 4<210\rangle$ satellites characteristic of the H-phase [17]. For the current alloy composition, formation of well-defined Hphase precipitates with such characteristic satellites was observed only after aging at $450{ }^{\circ} \mathrm{C}$ or higher temperatures [17].

The H-phase crystal structure arises from a redistribution of the $\mathrm{Zr}$ and $\mathrm{Ti}$ atoms within their sublattice of the B2 structure, which brings about the 3-fold and 4-fold periodicities along the $\langle 110\rangle$ and $\langle 210\rangle$ directions, corresponding to the characteristic satellites in the diffraction patterns [17]. Thus, the diffuse streaks observed after prolonged aging at $250{ }^{\circ} \mathrm{C}$ in the three microstructures seem to be related to the preliminary stages of such $\mathrm{Zr}$ and $\mathrm{Ti}$ atomic redistribution in the $\mathrm{B} 2$ matrix towards the $\mathrm{H}$-phase. The present results indicate that the limited diffusion at $250{ }^{\circ} \mathrm{C}$ only permits short range atomic reordering and it is not enough for the complete development of the 3-fold and 4-fold periodicities characteristic of the $\mathrm{H}$ phase, leading to diffuse streaks in the diffraction patterns instead of well-defined satellites. In fact, diffuse streaks similar to those shown in Fig. 2 were reported by Sandu et al. in $\mathrm{Ni}_{52} \mathrm{Ti}_{42} \mathrm{Zr}_{6}$ and were related to short range ordering of the $\mathrm{Zr}$ atoms as a previous step to the formation of precipitates by aging at $500{ }^{\circ} \mathrm{C}[4,5]$. Very recently, Couglin et al. reported similar diffuse streaks in a $\mathrm{Ni}_{51} \mathrm{Ti}_{29} \mathrm{Hf}_{20}$ alloy after hot extrusion at $900{ }^{\circ} \mathrm{C}$ and observed nanometric areas of enhanced intensity in high resolution High Angle Annular Dark Field (HAADF) images 
showing $n / 4<111>$ satellites in the Fast Fourier Transform, which were referred to as a new H' phase and considered as a precursor of the $\mathrm{H}$ phase [20]. The present diffraction patterns of $\mathrm{Ni}_{50.3} \mathrm{Ti}_{29.7} \mathrm{Zr}_{20}$ after prolonged $250{ }^{\circ} \mathrm{C}$ aging do not show any trace of $n / 4<111>$ satellites, indicating a state still previous to the H' precursor phase suggested in NiTiHf alloys, but not reported so far in $\mathrm{Zr}$ containing alloys.

Suppression of the MT after low temperature aging is well documented for Ni-rich $\mathrm{Ni}$ Ti binary alloys (see, for instance [21-24]). Kompatscher et al. detected $\sim 1 \mathrm{~nm}$ sized $\mathrm{Ni}_{4} \mathrm{Ti}_{3}$ precipitates in SHT alloys with high $\mathrm{Ni}$ excess ( 51 to 54 at\% $\mathrm{Ni}$ ) by means of small-angle neutron scattering, which formed during quenching. The precipitates grew to a size of $\sim 1.5 \mathrm{~nm}$ after additional aging at $280^{\circ} \mathrm{C}$ for $1 \mathrm{~h}$ [21]. Ji et al also reported nanometric $\mathrm{Ni}_{4} \mathrm{Ti}_{3}$ precipitates in the $\mathrm{Ni}_{51.3} \mathrm{Ti}_{48.7}$ alloy aged at $200{ }^{\circ} \mathrm{C}$ for $3 \mathrm{~h}$, which were responsible for strain-glass behavior of the alloy [23]. In these works, the MT suppression is attributed to the early stages of $\mathrm{Ni}_{4} \mathrm{Ti}_{3}$ precipitation [21-24].

Previous studies on Ni-rich Ni-Ti-Hf and Ni-Ti-Zr alloys have ruled out the precipitation of $\mathrm{Ni}_{4} \mathrm{Ti}_{3}$ phase and confirmed the formation of the H-phase in these ternary systems $[4,5,16,17]$. Thus, in analogy to the binary alloys and taking into account the effects observed by TEM (Fig. 2), the MT suppression observed in the present $\mathrm{Ni}_{50.3} \mathrm{Ti}_{29.7} \mathrm{Zr}_{20}$ alloy after aging at $250{ }^{\circ} \mathrm{C}$ (and, in some cases, just after a relatively slow quenching process) should be attributed to diffusive precursor effects of the $\mathrm{H}$-phase precipitation. As the $\mathrm{H}$ phase is richer in $\mathrm{Zr}$ and lean in $\mathrm{Ti}$ compared to the B2 matrix [17], the process at low temperatures probably starts with a short range segregation of $\mathrm{Zr}$ and $\mathrm{Ti}$ atoms leading to the formation of very small domains (roughly nanometric in size) with "modified" and "normal" compositions, which explains the finely mottled contrast observed in conventional bright field TEM images. In this state, the ultrafine domains with "normal" composition would be smaller than the critical size needed for nucleation and growth of martensite, preventing the transformation, whereas the domains with "modified" composition are still too small for the complete development of the $\mathrm{H}$ phase superstructure (note that one lattice parameter of the $\mathrm{H}$ phase unit cell is as large as $2.6 \mathrm{~nm}$ [17]). Further detailed characterization of the new state issued from low temperature aging is in progress to understand the mechanism underlying the complete MT suppression. 
The stability of the MT of $\mathrm{Ni}_{50.3} \mathrm{Ti}_{29.7} \mathrm{Zr}_{20}$ under thermal cycling has also been studied for the three initial microstructures produced by SHT, 550C and FC treatments to evaluate the effect of short term exposures to relatively high temperatures in austenite. Fig. 3a presents the DSC curves of the first 20 cycles for two SHT samples cycled to two different upper cycle temperatures: $100{ }^{\circ} \mathrm{C}$ (upper curves in black) and $150{ }^{\circ} \mathrm{C}$ (bottom curves in red). It is worth noting the different transformation temperatures of these two samples in the first cycle and the fact that they show a single transformation peak, in contrast to the sample shown in Fig. 1. These results illustrate the variability in the behavior of the SHT condition for the $\mathrm{Ni}_{50.3} \mathrm{Ti}_{29.7} \mathrm{Zr}_{20}$ alloy, as mentioned previously. Fig. $3 \mathrm{~b}$ shows the peak temperatures of the forward and reverse transformations $(M p$ and $A p$, respectively) for an SHT sample plotted as a function of the cycle number. There is a progressive decrease of $M p$ by $\sim 30^{\circ} \mathrm{C}$ after 20 cycles when the upper cycle temperature is $100{ }^{\circ} \mathrm{C}$ (slightly higher than the austenite finish temperature), which increases to $\sim 50{ }^{\circ} \mathrm{C}$ when the upper temperature is raised to $150{ }^{\circ} \mathrm{C}$.

A decrease of TTs upon thermal cycling is also well documented in SHT binary Ni-Ti alloys (e.g. [25-29]) and it is generally attributed to the formation of dislocations with cycling. Fig. 4 shows the typical dislocation arrays generated after 20 cycles in the present $\mathrm{Ni}_{50.3} \mathrm{Ti}_{29.7} \mathrm{Zr}_{20}$ SHT material, which are relatively moderate in density and may partially contribute to the observed decrease of TTs with cycling. However, the observed upper temperature effect on the cycling evolution reflects the existence of diffusive effects in the form of short range atomic reordering during the time spent in the austenite phase during each thermal cycle, which also contributes to the decrease of TTs with cycling. This is confirmed by additional experiments consisting of holding another SHT sample in the DSC at $100{ }^{\circ} \mathrm{C}$ for $40 \mathrm{~min}$ before the $2^{\text {nd }}$ thermal cycle and 80 min before the $5^{\text {th }}$ cycle. The results are marked as blue diamonds in Fig. 3b, where it becomes clear that such dwell times at $100{ }^{\circ} \mathrm{C}$ cause a larger drop in $M p$ compared to the normal cycling sequence. A similar behavior has been recently observed in the binary $\mathrm{Ni}_{50.6} \mathrm{Ti}_{49.4}$ alloy with subambient $\mathrm{TTs}$, for which the effect of thermal cycling is notably enhanced when the sample is aged at room temperature between each consecutive cycle [30]. Nevertheless, the authors propose a different microscopic origin in terms of interaction between dislocations and point defects generated from high temperature $\left(1000^{\circ} \mathrm{C}\right)$ quenching [30]. 
The shift of DSC peak temperatures is less pronounced for the reverse MT than for the forward transition, which results in an increase of MT hysteresis of the SHT samples after 20 cycles by $27^{\circ} \mathrm{C}$ and $20^{\circ} \mathrm{C}$ for upper cycle temperatures of $100{ }^{\circ} \mathrm{C}$ and $150{ }^{\circ} \mathrm{C}$, respectively. The increase in the MT hysteresis is mostly attributed to the dislocation activity and is actually less severe when cycled to a higher temperature. Therefore, increasing the upper cycle temperature and thus reordering effects are much more detrimental to the $M p$ temperature than the overall hysteresis in the material.

The 550C and FC samples (containing well developed H-phase precipitates) were thermally cycled up to $250^{\circ} \mathrm{C}$ due to their higher TTs. As seen in Fig. 3c, the 550C sample experiences a continuous drop in peak temperatures by $\sim 30 \mathrm{~K}$ after 20 cycles. In this case, the dislocation generation during MT cycling should be notably reduced due to the strengthening effect of the nanoprecipitates introduced with the 550C treatment, which is reflected in a lower MT hysteresis and better superelasticity in relation to the SHT condition [18]. Consequently, for the 550C material, the evolution of MT with cycling is mostly dominated by the short range atomic reordering effect in the B2 matrix. For the FC state, the $M p$ temperature decreases slightly in the first 8 cycles and then remains constant, while the $A p$ temperature shows a small continuous increase (Fig. 3c), which causes an increase of $\sim 12 \mathrm{~K}$ in the MT hysteresis after 20 cycles. After slow furnace cooling, the B2 matrix composition is closer to equilibrium at low temperatures due to the intense H-phase precipitation process and, thus, the short range reordering effect should be strongly diminished. This is consistent with the longer aging times needed to suppress the MT in the FC samples in the prolonged aging experiments at $250^{\circ} \mathrm{C}$ (Fig. 1). Similar to the SHT case, the slight increase in hysteresis during thermal cycling in the FC state should be attributed to moderate dislocation generation. In fact, our previous work indicates a notably lower strengthening effect of the large H-phase precipitates in the FC material compared to the 550C case [18].

In conclusion, the present results show that the selected distributions of H-phase precipitates resulting from 550C and FC thermal treatments are not noticeably modified after prolonged aging at $250{ }^{\circ} \mathrm{C}$. However, the B2 phase of $\mathrm{Ni}_{50.3} \mathrm{Ti}_{29.7} \mathrm{Zr}_{20}$ is unstable at low temperatures and undergoes short range atomic reordering processes producing diffuse streaks in the diffraction patterns. These processes are interpreted in terms of a short range redistribution of the $\mathrm{Ti}$ and $\mathrm{Zr}$ atoms as a precursor state to the $\mathrm{H}$-phase 
precipitation. This $\mathrm{B} 2$ phase instability results in dramatic effects on the functional properties of the $\mathrm{Ni}_{50.3} \mathrm{Ti}_{29.7} \mathrm{Zr}_{20}$ alloy, with a complete suppression of the martensitic transformation after prolonged aging at $250{ }^{\circ} \mathrm{C}$. Because of a moderate generation of dislocations, the B2 phase instability is also predominantly responsible for the observed shift in MT temperatures with thermal cycling.

Partial financial support from the Spanish MINECO and FEDER under project MAT2014-56116-C4-1-R and FPI grant BES-2012-053863 are acknowledged. RDN gratefully acknowledges support from the NASA Transformative Aeronautics Concepts Program (TACP), Transformational Tools \& Technologies Project. Partial support was also provided by the US Air Force Office of Scientific Research, under Grant no. FA9550-15-1-0287, the US National Science Foundation under Grant no. CMMI 1534534, and under Grant no. DMR08-44082, which supports the International Materials Institute for Multifunctional Materials for Energy Conversion (IIMEC) at Texas A\&M University.

\section{REFERENCES}

[1] K. Otsuka, C.M. Wayman, Shape Memory Materials, Cambridge University Press, Cambridge, 1998.

[2] J. Ma, I. Karaman and R.D. Noebe, Int. Mater. Rev. 55 (2010) 257.

[3] X.L. Meng, W. Cai, F. Chen and L.C. Zhao, Scripta Mater 54 (2006) 1599.

[4] A.M. Sandu, K. Tsuchiya, S. Yamamoto, Y. Todaka and M. Umemoto, Scripta Mater. 55 (2006) 1079.

[5] A.M. Sandu, K. Tsuchiya, M. Tabuchi, S. Yamamoto, Y. Todaka and M. Umemoto, Mater. Trans. 48 (2007) 432.

[6] X.L. Meng, W. Cai, Y.D. Fu, Q.F. Li, J.X. Zhang, L.C. Zhao, Intermetallics 16 (2008) 698.

[7] H.E. Karaca, S.M. Saghaian, B. Basaran, G.S. Bigelow, R.D. Noebe, Y.I.

Chumlyakov, Scripta Mater. 65 (2011) 577

[8] G.S. Bigelow, A. Garg, S.A. Padula II, D.J. Gaydosh, R.D. Noebe, Scripta Mater. 64 (2011) 725-728. 
[9] O. Benafan, R.D. Noebe, S.A. Padula and R. Vaidyanathan. Metall. Mater. Trans. A 43 (2012) 4539-4552.

[10] D.R. Coughlin, P.J. Phillips, G.S. Bigelow, A. Garg, R.D. Noebe, M.J. Mills, Scripta Mater. 67 (2012) 112-115.

[11] A. Evirgen, F. Basner, I. Karaman, R. Noebe, J. Pons, R. Santamarta, Funct. Mater. Lett. 5 (2012) 1250038.

[12] H.E. Karaca, S.M. Saghaian, G. Ded, H. Tobe, B. Basaran, H.J. Maier, R.D. Noebe, Y.I. Chumlyakov, Acta Mater. 61 (2013) 7422.

[13] A. Evirgen, I. Karaman, R.D. Noebe, R. Santamarta, J. Pons, Scripta Mater. 69 (2013) 354.

[14] O. Benafan, A. Garg, R.D. Noebe, G.S. Bigelow, S.A. Padula, D.J. Gaydosh, N. Schell, J.H. Mabe, R. Vaidyanathan. Intermetallics 50 (2014) 94.

[15]A.P. Stebner, G.S. Bigelow, J. Yang, D.P. Shukla, S.M. Saghaian, R. Rogers, A. Garg, H.E. Karaca, Y. Chumlyakov, K. Bhattacharya, R.D. Noebe, Acta Mater. 76 (2014) 40.

[16] F. Yang, D.R. Coughlin, P.J. Phillips, L. Yang, A. Devaraj, R.D. Noebe, M.J. Mills, Acta Mater 61 (2013) 3335.

[17] R. Santamarta, R. Arróyave, J. Pons, A. Evirgen, I. Karaman, H.E. Karaca, R.D. Noebe, Acta Mater. 61 (2013) 6191.

[18] A. Evirgen, I. Karaman, R. Santamarta, J. Pons, R.D. Noebe, Scripta Mater. 81 (2014) 12.

[19] A. Evirgen, I. Karaman, J. Pons, R. Santamarta, R.D. Noebe, Mater. Sci. Eng. A 655 (2016) 193.

[20] D. R. Coughlin, L. Casalena, F. Yang, R. D. Noebe, M. J. Mills, J. Mater. Sci. 51 (2016) 766.

[21] M. Kompatscher, B. Demé, G. Kostorz, Ch. Somsen, E.F. Wassermann, Acta Mater. 50 (2002) 1581.

[22] Y. Zheng, F. Jiang, L. Li, H. Yang, Y. Liu, Acta Mater. 56 (2008) 736.

[23] Y. Ji, X. Ding, T. Lookman, K. Otsuka, X. Ren, Phys. Rev. B 87 (2013) 104110.

[24] S. Kustov, B. Mas, D. Salas, E. Cesari, S. Raufov, V. Nikolaev, J. Van Humbeeck, Scripta Mater. 103 (2015) 10.

[25] G.D. Sandrock, A.J. Perkins, R.F. Hehemann, Metall. Trans. 2 (1971) 2769.

[26] S. Miyazaki, Y. Igo, K. Otsuka, Acta Metall. 34 (1986) 2045. 
[27] D.M. Norfleet, P.M. Sarosi, S. Manchiraju, M.F.X. Wagner, M.D. Uchic, P.M. Anderson, M.J. Mills, Acta Mater. 57 (2009) 3549.

[28] T. Simon, A. Kröger, C. Somsen, A. Dlouhy, G. Eggeler, Acta Mater. 58 (2010) 1850 .

[29] A.R. Pelton, G.H. Huang, P. Moine, R. Sinclair, Mater. Sci. Eng. A 532 (2012) 130.

[30] X. Wang, J. Van Humbeeck, B. Verlinden, S. Kustov, Scripta Mater. 113 (2016) 206.

\section{FIGURE CAPTIONS}

Figure 1: DSC thermograms of the $\mathrm{Ni}_{50.3} \mathrm{Ti}_{29.7} \mathrm{Zr}_{20}$ alloy after different aging times at $250{ }^{\circ} \mathrm{C}$ for (a) SHT, (b) $550 \mathrm{C}$ and (c) FC initial thermal treatments.

Figure 2: Electron diffraction patterns ([001], [1̄ㅣ] and [1ํ1] zone axes) of the $\mathrm{Ni}_{50.3} \mathrm{Ti}_{29.7} \mathrm{Zr}_{20}$ alloy after aging at $250^{\circ} \mathrm{C}$ for 7 weeks. (a), (b), (c): SHT condition ; (d), (e), (f): 550C treatment.

Figure 3: (a) Evolution of the DSC transformation peak with thermal cycling for two upper cycle temperatures (UCT): $100{ }^{\circ} \mathrm{C}$ (upper curves in black) and $150{ }^{\circ} \mathrm{C}$ (lower curves in red). (b) $M p$ and $A p$ temperatures for SHT samples cycled up to $100{ }^{\circ} \mathrm{C}$ (circles) and $150^{\circ} \mathrm{C}$ (triangles) upper temperatures. (c) $M p$ and $A p$ temperatures for 550C (circles) and FC (triangles) samples cycled up to $250^{\circ} \mathrm{C}$.

Figure 4: TEM micrograph of dislocation arrays formed after 20 thermal cycles in $\mathrm{Ni}_{50.3} \mathrm{Ti}_{29.7} \mathrm{Zr}_{20}$ SHT material. 

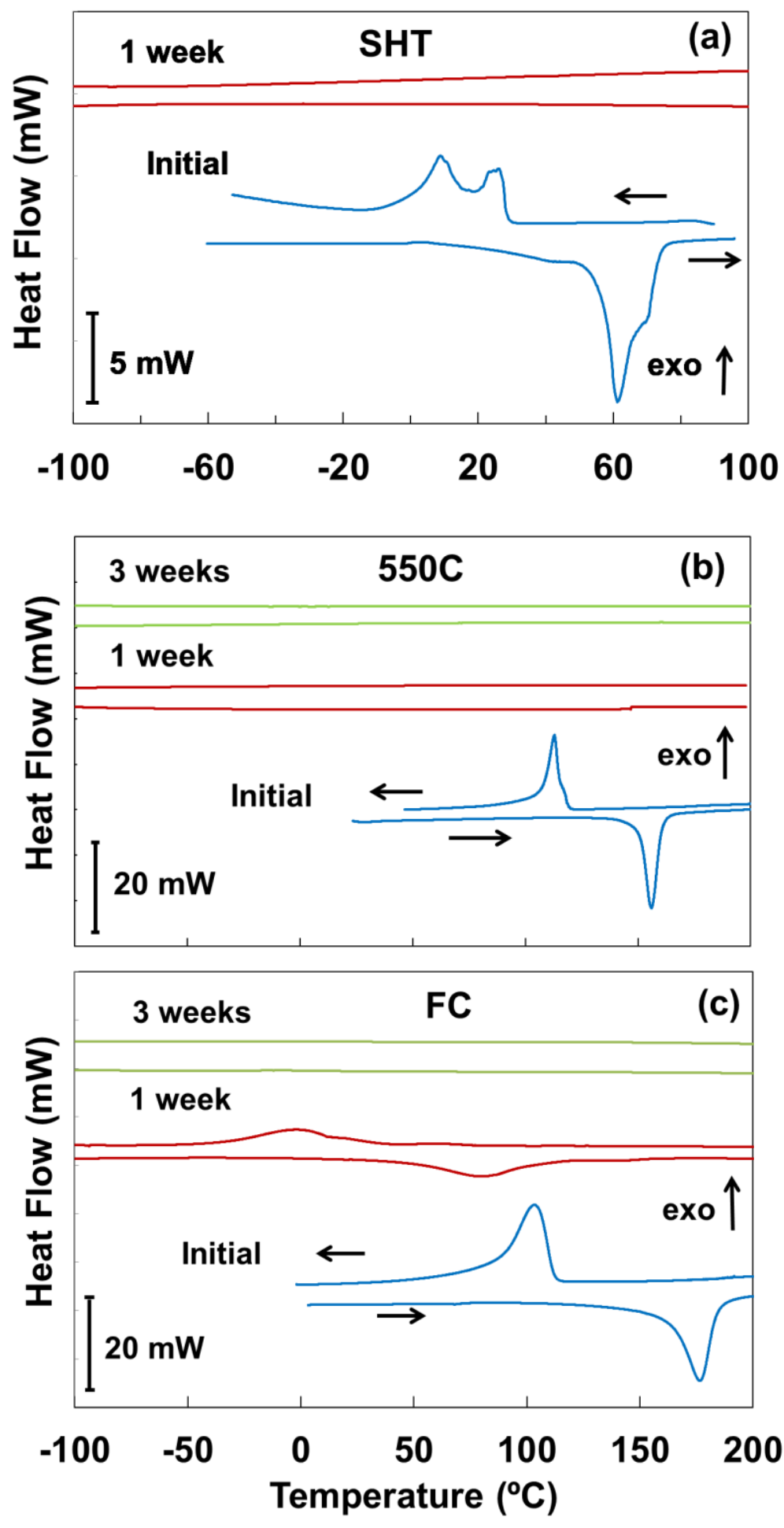

Figure 1: DSC thermograms of the $\mathrm{Ni}_{50.3} \mathrm{Ti}_{29.7} \mathrm{Zr}_{20}$ alloy after different aging times at $250{ }^{\circ} \mathrm{C}$ for (a) SHT, (b) $550 \mathrm{C}$ and (c) FC initial thermal treatments. 


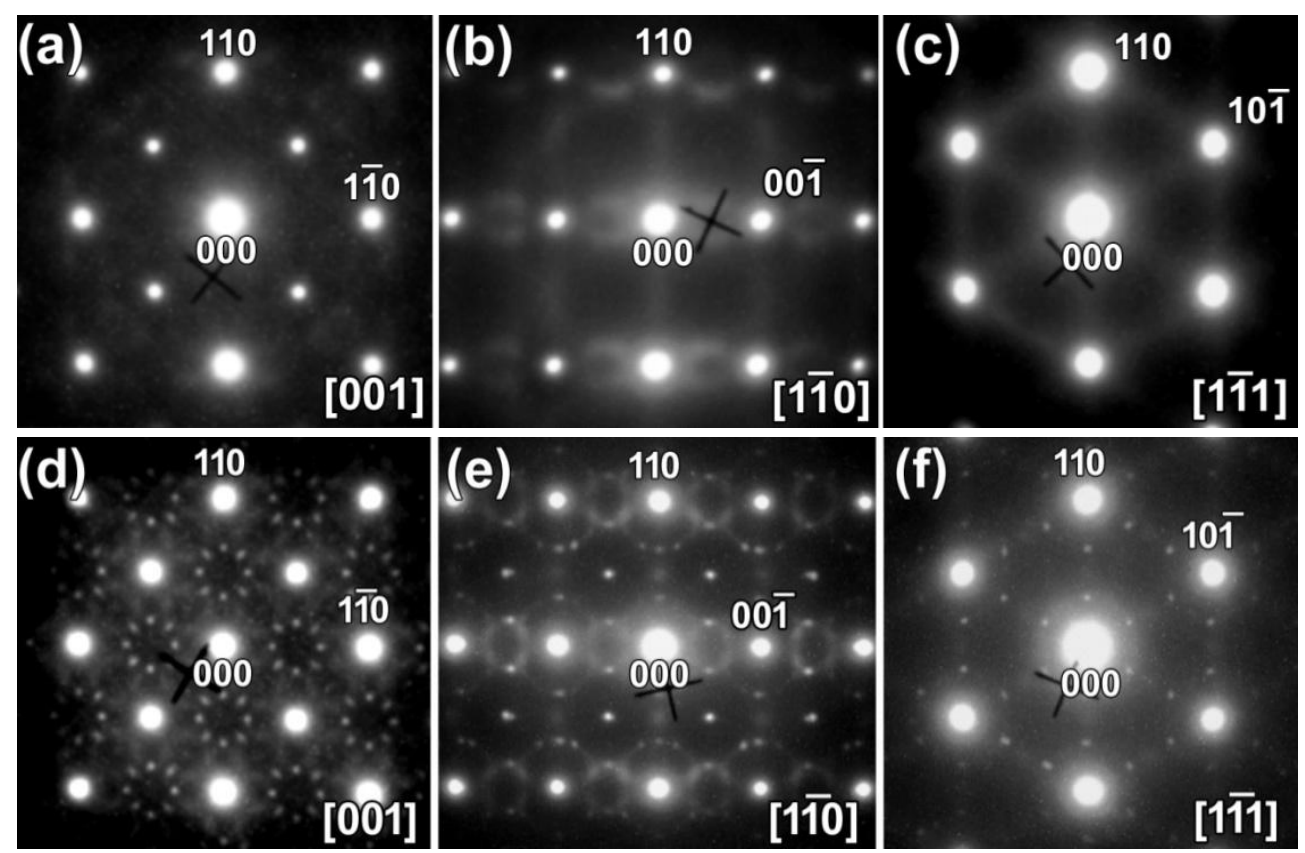

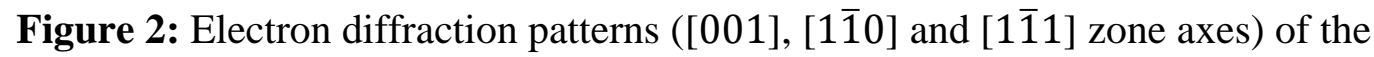
$\mathrm{Ni}_{50.3} \mathrm{Ti}_{29.7} \mathrm{Zr}_{20}$ alloy after aging at $250{ }^{\circ} \mathrm{C}$ for 7 weeks. (a), (b), (c): SHT condition ; (d), (e), (f): 550C treatment. 

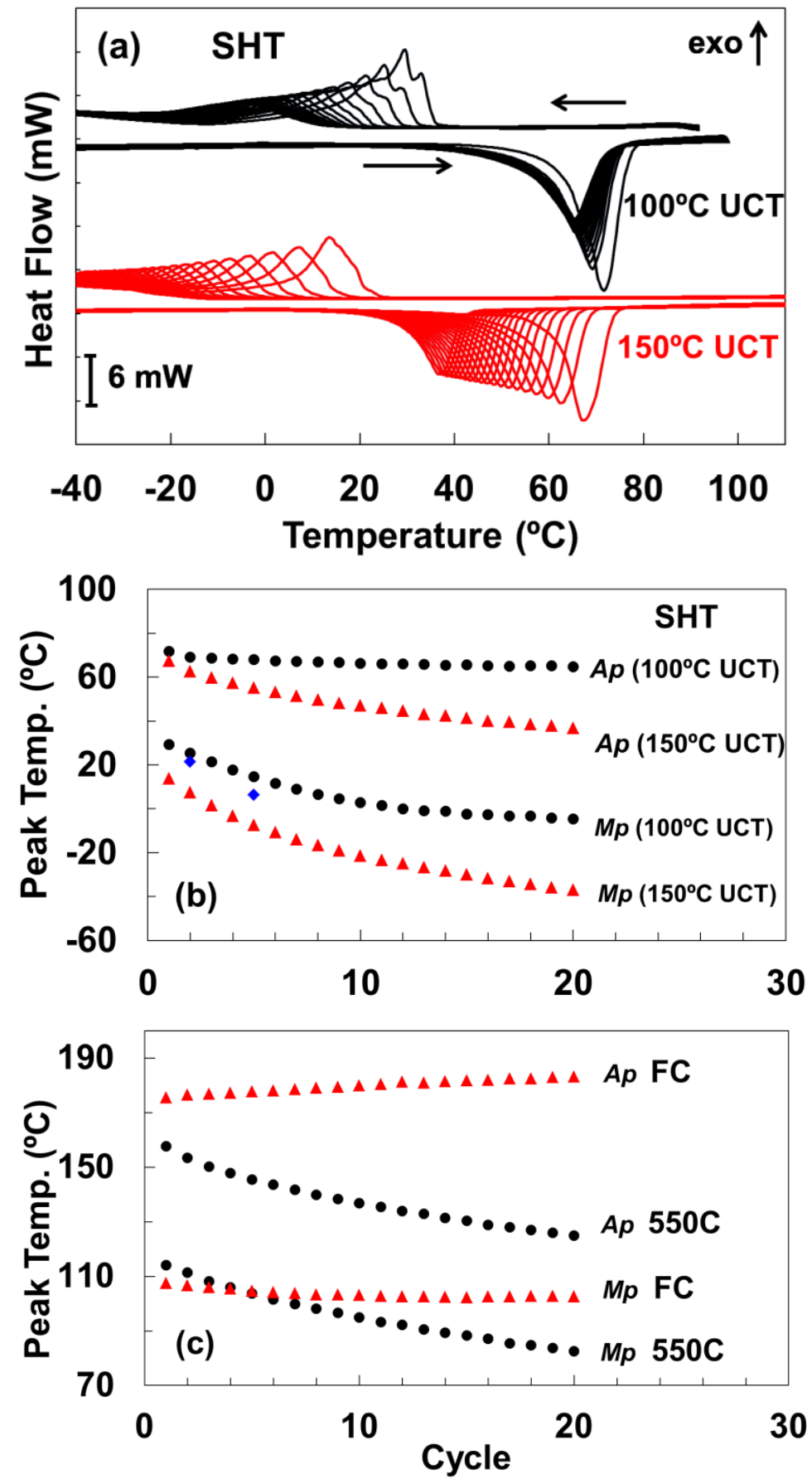

Figure 3: (a) Evolution of the DSC transformation peak with thermal cycling for two upper cycle temperatures (UCT): $100{ }^{\circ} \mathrm{C}$ (upper curves in black) and $150{ }^{\circ} \mathrm{C}$ (lower curves in red). (b) $M p$ and $A p$ temperatures for SHT samples cycled up to $100{ }^{\circ} \mathrm{C}$ (circles) and $150^{\circ} \mathrm{C}$ (triangles) upper temperatures. (c) $M p$ and $A p$ temperatures for 550C (circles) and FC (triangles) samples cycled up to $250^{\circ} \mathrm{C}$. 


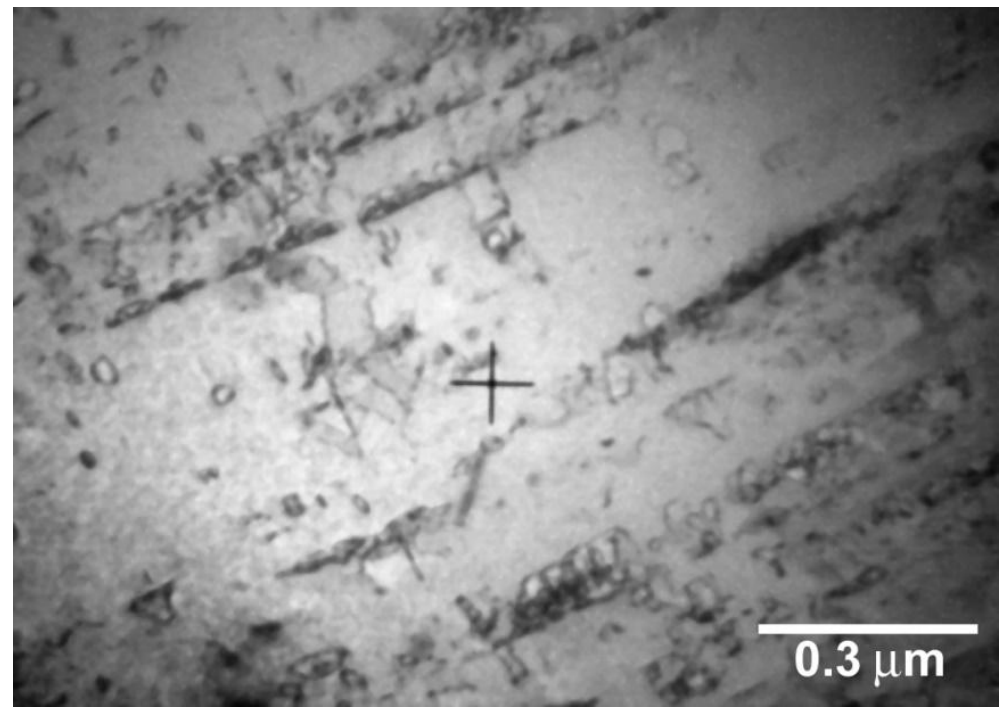

Figure 4: TEM micrograph of dislocation arrays formed after 20 thermal cycles in $\mathrm{Ni}_{50.3} \mathrm{Ti}_{29.7} \mathrm{Zr}_{20}$ SHT material. 


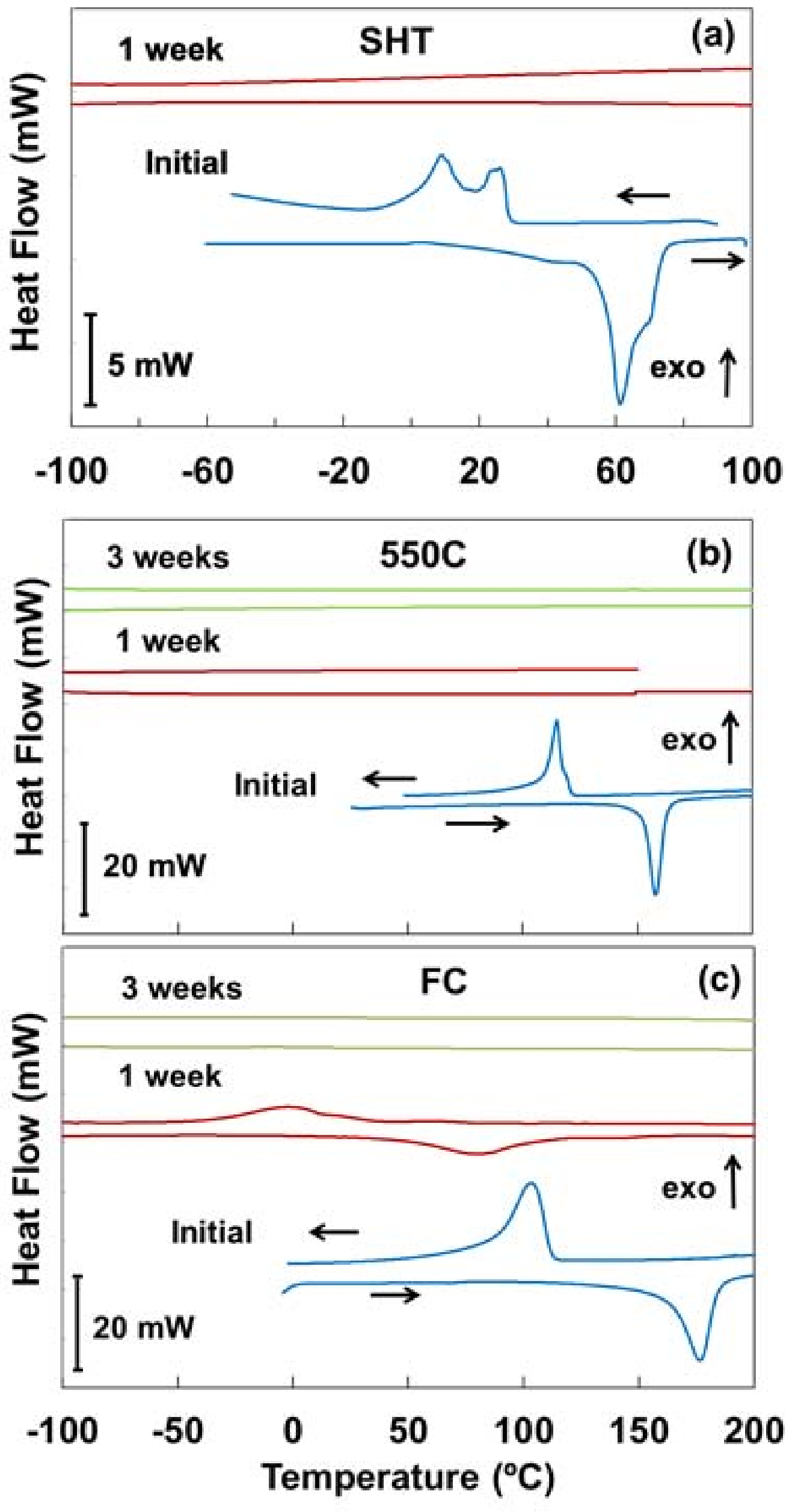

